\title{
NOTEWORTHY RECORDS OF THE LICHENIZED AND LICHENICOLOUS FUNGI FROM ALACADAĞ NATURE RESERVE (FİNIKE-ANTALYA) IN THE MEDITERRANEAN REGION OF TURKEY
}

\author{
KARAGÜNLÜ, G. ${ }^{1}$ - TUFAN-ÇETIN, Ö. ${ }^{2 *}$ \\ ${ }^{I}$ Institute of Natural and Applied Sciences, Akdeniz University, Antalya, Turkey \\ ${ }^{2}$ Program of Environmental Protection and Control, Department of Environmental Protection \\ Technology, Vocational School of Technical Sciences, Akdeniz University, Antalya, Turkey \\ (phone: +90-242-310-6758; fax: +90-242-227-4785) \\ ${ }^{*}$ Corresponding author \\ e-mail: ozgetufan@akdeniz.edu.tr \\ (Received $9^{\text {th }}$ Oct 2019; accepted $30^{\text {th }}$ Jan 2020)
}

\begin{abstract}
Alacadağ, due its different vegetation composition, has been declared as Nature Protection Area in Antalya in Turkey. The special vegetation composition may sign that special lichen taxa can be found in the area. Therefore, the richness of the lichenized and lichenicolous fungi of the area was determined. According to results, a total of 125 taxa belonging to 9 orders, 27 families and 66 genera were identified. Three of these taxa are lichenicolous fungi living parasitically on lichens. Of these three, Abrothallus welwitschii Tul. ex Mont. is newly recorded from Turkey. In addition, lichenized fungi Calicium pinicola (Tibell) M. Prieto \& Wedin, Catapyrenium psoromoides (Borrer) R. Sant., Parmelia ernstiae Feuerer \& A. Thell., Sticta limbata (Sm.) Ach. were reported firstly in Turkey with this research. Of all determined taxa for the area and thirty-three taxa for Antalya Province are new. Fourteen taxa that had been known as specific to different geographical regions of Turkey before, were first record from Mediterranean region of the country. In addition, it is concluded that the species richness composition of Alacadağ Nature Protection Area showed low similarity to nearby compared areas. It was determined that many of these dissimilar taxa are only species that can live in good environmental conditions.
\end{abstract}

Keywords: biodiversity, lichen, lichen systematic, systematic

\section{Introduction}

Lichens are symbiotic association of fungi and algae and/or cyanobacteria (Hawksworth, 1991; Yuan et al., 2005; Tripp, 2017). This complex association makes it difficult to classify these organisms. However, photobiont partners have their own classifications. For this reason, the identification of "lichen species" is carried out by the classification of the fungus that can form lichen (lichenized fungi). In the world and Turkey, many studies on the classification of these interesting organisms have been done. In addition, parasitic fungi taxa on lichens (lichenicolous fungi) were also included in these studies. Feuerer and Hawksworth (2007) reported that a total of 18.882 lichenized and lichenicolous fungi were recorded worldwide. A book entitled "Türkiye Likenleri Listesi- A Checklist of the Lichens of Turkey" (John and Turk, 2017), based on previous studies, reported that totally 1898 taxa of lichenized and lichenicolous fungi had been determined in Turkey.

Lichens are highly diverse in protected areas without human intervention (Hilmo and Såstad, 2001; Gauslaa et al., 2007; Knapp et al., 2008). Therefore, protected areas are very valuable in terms of lichens. Protected areas in Turkey are divided into four statuses: national parks, nature parks, nature monuments and nature protection area 
(MPK, 1983). Nature protection areas are the least destructed of these areas by human intervention. Nature protection areas are defined as;

- A part of nature which contains rare examples of ecosystems.

- Species and natural phenomena that are rare.

- Endangered ecosystems which are important for science and education.

- Require absolute protection and are reserved for science use only and educational purposes (MPK, 1983).

Of the IUCN protected area categories (Dudley, 2008; Mitchell et al., 2018), the Absolute Nature Reserve and Wilderness category is equivalent to the Nature Protection Area (Eroğlu, 2014). Alacadağ Nature Protection Area is one of the rare areas that is located in Antalya Province in the Mediterranean Region of Anatolia. It is a special forest formed of more than 20 tree species that are rare, old and/or monumental. Cedrus libani A. Rich., Pinus brutia Ten., Juniperus oxycedrus L., Quercus coccifera L., Fraxinus angustifolia Wahl., Acer platanoides L., Pistacia terebinthus L., Ostrya carpinifolia Scop., Fraxinus ornus L., Sorbus torminalis (L.) Crantz. are some of these tree species. The vegetation composition of the area is even different than its near surroundings. Due to this feature, the area was declared a nature protection area in 01.10.1990. This special vegetation composition suggests that the area is rich in terms of lichen richness. Thus, the lichenized and lichenicolous fungi richness of the Alacadag Nature Protection Area is found to be worth investigating and this formed the purpose of this study.

\section{Materials and methods}

\section{Study area}

Alacadağ Nature Protection Area is located in the Mediterranean Region of Anatolia at the western slopes of Alacadağ Mountain, with the Neighborhood of Alacadağ, District of Finike, Antalya Province Area which is $15 \mathrm{~km}$ away from the district of Finike and $128 \mathrm{~km}$ away from Antalya, between the coordinates: $36^{\circ} 21^{\prime} 31^{\prime \prime} \mathrm{N}$ $30^{\circ} 02^{\prime} 14^{\prime \prime} \mathrm{E}, 36^{\circ} 21^{\prime} 24^{\prime \prime} \mathrm{N} 30^{\circ} 03^{\prime} 04^{\prime \prime} \mathrm{E}-36^{\circ} 23^{\prime} 27^{\prime \prime N} 30^{\circ} 03^{\prime} 04^{\prime \prime E}, 36^{\circ} 23^{\prime} 41^{\prime \prime} \mathrm{N} 30^{\circ} 03^{\prime} 49^{\prime \prime} \mathrm{E}$ The total area is 427 hectares and the altitude varies between 884 - 1809 m (Figure 1).

\section{Collecting of samples}

The lichen samples had been collected from all substrates in Alacadağ Nature Protection Area in 2016 and deposited in the private fungarium Dr. Özge Tufan-Çetin. 398 lichen samples were collected. Field studies were carried out in selected 8 random localities that have different vegetation cover types, topographic structure, microclimate characteristics and altitudes (Table 1, Figure 1, Figure 2, Figure 3).

\section{Identification of samples}

Dried samples were examined by using a light microscope (Nikon Eclipse E100) for microscopic characters; and a stereoscopic zoom microscope (Nikon SMZ745T) for macroscopic characters. For identification of the species, the following literature has been used: Clauzade and Roux (1985), Wirth et al. (1995), Smith et al. (2009), Moberg (1977), Tucker and Thiers (1998), Ihlen and Wedin (2008), Arup et al. (2013), Otálora et al. (2014). When required, spot tests, UV tests and TLC has also been carried out. Index Fungorum (2018) website was used in order to update the names of lichens taxa. 


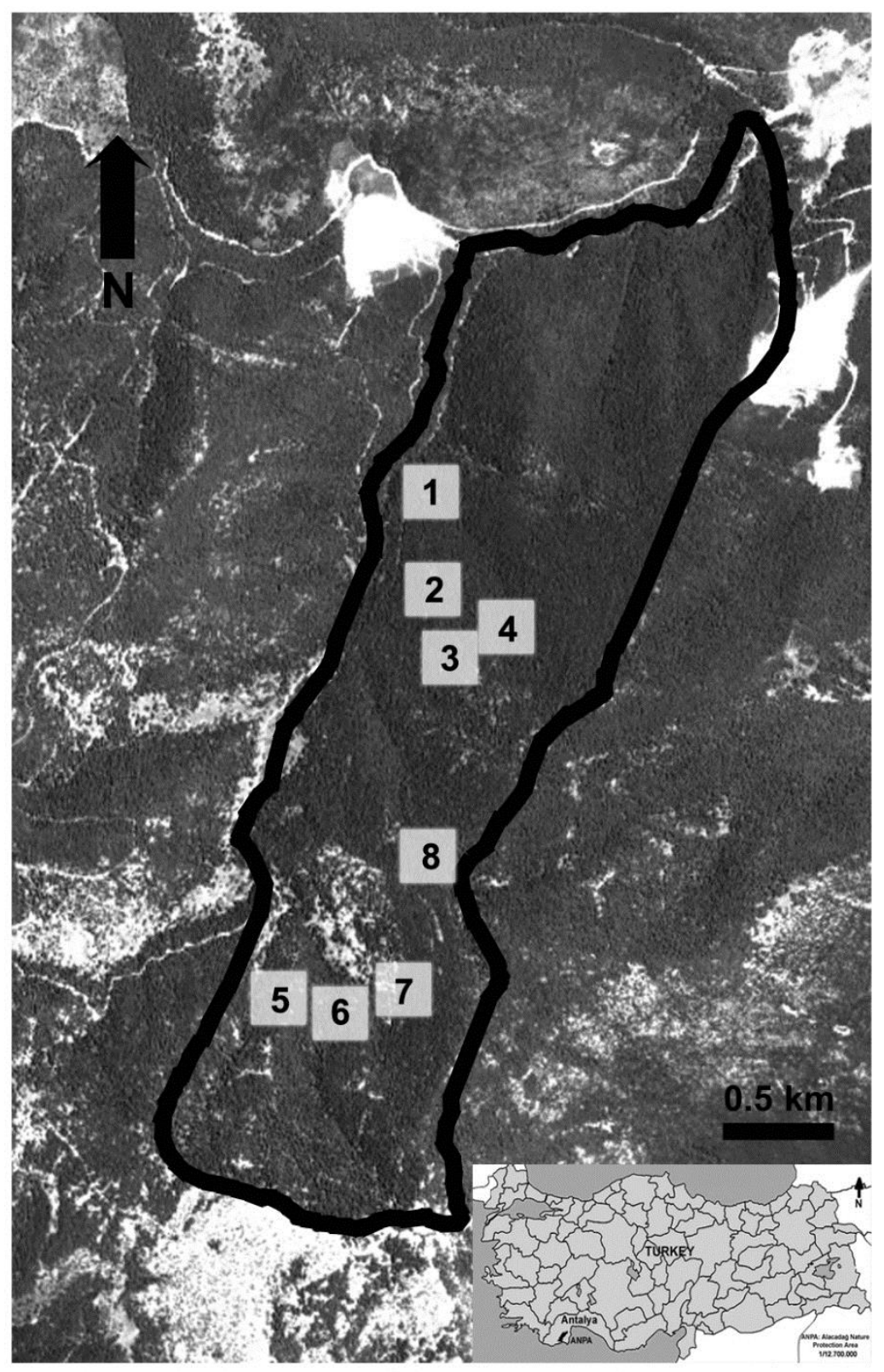

Figure 1. The map of Alacadag Nature Area and the localities where the fieldwork was performed (The map was created with Adobe Photoshop 7.0 via data obtained from Google Earth Pro 7.3 program)

Table 1. Information about localities in Alacadağ Nature Protection Area

\begin{tabular}{c|c|c|c}
\hline Localites & Coordinates & Altitudes & Dates \\
\hline Loc 1 & $36^{\circ} 22,855^{\prime} \mathrm{N} 30^{\circ} 02,822^{\prime} \mathrm{E}$ & $1185 \mathrm{~m}$ & 18.6 .2016 \\
Loc 2 & $36^{\circ} 22,667^{\prime} \mathrm{N} 30^{\circ} 02,854^{\prime} \mathrm{E}$ & $1343 \mathrm{~m}$ & 18.6 .2016 \\
Loc 3 & $36^{\circ} 22,577^{\prime} \mathrm{N} 30^{\circ} 03,008^{\prime} \mathrm{E}$ & $1494 \mathrm{~m}$ & 18.6 .2016 \\
Loc 4 & $36^{\circ} 22,533^{\prime} \mathrm{N} 30^{\circ} 02,915^{\prime} \mathrm{E}$ & $1449 \mathrm{~m}$ & 18.6 .2016 \\
Loc 5 & $36^{\circ} 21.868^{\prime} \mathrm{N} 30^{\circ} 02.490^{\prime} \mathrm{E}$ & $1547 \mathrm{~m}$ & 19.6 .2016 \\
Loc 6 & $36^{\circ} 21,862^{\prime} \mathrm{N} 30^{\circ} 02,638^{\prime} \mathrm{E}$ & $1516 \mathrm{~m}$ & 19.6 .2016 \\
Loc 7 & $36^{\circ} 21,895^{\prime} \mathrm{N} 30^{\circ} 02,781^{\prime} \mathrm{E}$ & $1528 \mathrm{~m}$ & 19.6 .2016 \\
Loc 8 & $36^{\circ} 22,153^{\prime} \mathrm{N} 30^{\circ} 02,855^{\prime} \mathrm{E}$ & $1609 \mathrm{~m}$ & 19.6 .2016 \\
\hline
\end{tabular}




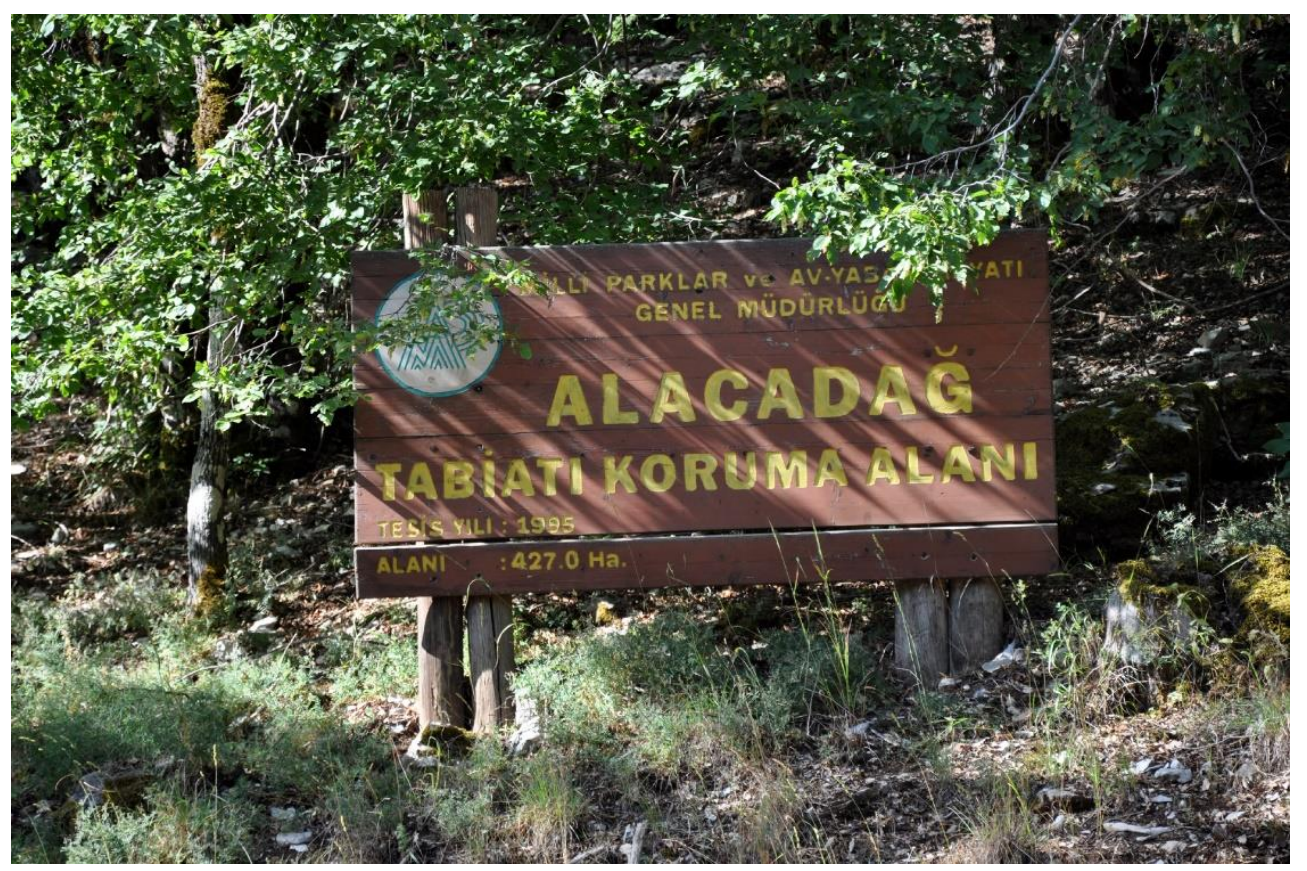

Figure 2. Entrance of Alacadağ Nature Protection Area (Nature Reserve) Finike-Antalya

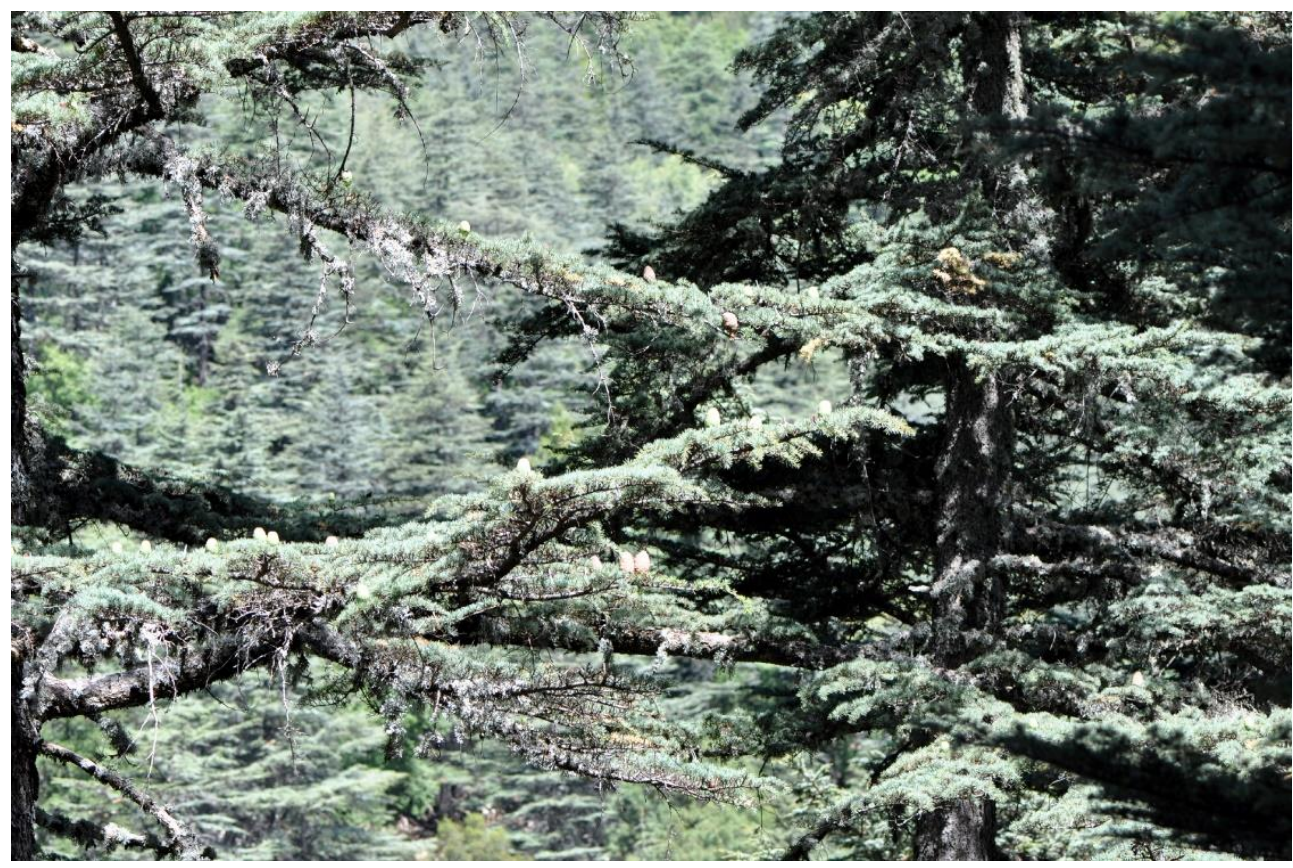

Figure 3. A view from Alacada $\breve{g}$ Nature Protection Area (Nature Reserve) Finike-Antalya

\section{Data analysis}

The lichen richness data obtained from Alacadağ Nature Protection Area and the data obtained from near and previously studied areas were compared. These areas are the Elmalı Cedar Research Forest and Termessos National Park. The data from Elmalı Cedar Research Forest with altitudes from 1300 to 1880, approximately $23 \mathrm{~km}$ away from Alacadağ, were recorded by Çobanoglu and Sevgi (2006). Data of Termessos 
National Park with altitudes from 360 to $1665 \mathrm{~m}$, approximately $75 \mathrm{~km}$ away from Alacadağ, were determined by Tufan et al. (2005). The similarities of these three areas were calculated using Sorensen similarity index (Sørensen, 1948) with PAST 3.14. Since the richness of lichenicolous fungi had not been found in previous studies, these taxa were not included in the similarity assessment. In addition by Çobanoğlu and Sevgi (2006), the richness of epiphytic lichens had been investigated in the Elmalı Cedar Research Forest. Therefore, the similarity study for this area was applied only for epiphytic lichens.

\section{Results}

\section{Results of taxa identification}

This study is the first comprehensive study to determine the lichenized and the lichenicolous fungi species in the Alacadağ Nature Protection Area (Antalya-Finike). As a result of the field studies, 398 specimens collected and identified. A total of 125 taxa belonging to 9 orders, 27 families and 66 genera were determined with laboratory studies. They are listed in alphabetic order below. Taxa new for Turkey are marked by a plus (+) and taxa new for Antalya province are highlighted by an asterisk (*) in the list. In addition, lichenicolous fungi are indicated with a hash (\#):

\# Abrothallus parmeliarum (Sommerf.) Arnold, Loc 3 on lichen on Cedrus libani.

$+\# *$ Abrothallus welwitschii Tul. ex Mont, Loc 1 on lichen on Acer sp.

Acarospora cervina A.Massal., Loc 5 on calcareous rock.

Acarospora glaucocarpa (Ach.) Körb., Loc 5 on calcareous rock.

Acarospora macrospora (Hepp) Bagl., Loc 5 on calcareous rock.

Amandinea punctata (Hoffm.) Coppins \& Scheid., Loc 2 on Cedrus libani.

Anaptychia ciliaris (L.) Körb. ex A.Massal., Loc 1, Loc 2, Loc 3 on Cedrus libani;

Loc 3, Loc 8 on Juniperus excelsa; Loc 8 on Acer sp.; Loc 4 on dead tree.

* Arthonia didyma Körb., Loc 2 on Acer sp.

* Arthonia mediella Nyl., Loc 2 on Cedrus libani.

Bagliettoa calciseda (DC.) Gueidan \& Cl.Roux, Loc 4, Loc 5 on calcareous rock.

Bagliettoa cazzae (Zahlbr.) Vězda \& Poelt, Loc 2 on calcareous rock.

Bagliettoa marmorea (Scop.) Gueidan \& Cl.Roux, Loc 5 on calcareous rock.

Bagliettoa parmigera (J.Steiner) Vězda \& Poelt, Loc 4, Loc 5 on calcareous rock.

Bagliettoa parmigerella (Zahlbr.) Vězda \& Poelt, Loc 5 on calcareous rock.

Bilimbia sabuletorum (Schreb.) Arnold, Loc 4 on moss on calcareous rock.

Blastenia ferruginea (Huds.) A.Massal., Loc 3 on Cedrus libani.

Bryoria fuscescens (Gyelnik) Brodo \& D.Hawksw., Loc 5, Loc 6, Loc 7 on Cedrus libani.

* Bryoria nadvornikiana (Gyeln.) Brodo \& D.Hawksw., Loc 1 on Cedrus libani.

+ Calicium pinicola (Tibell) M. Prieto \& Wedin, Loc 3 on death tree.

* Calicium trabinellum (Ach.) Ach, Loc 3 on dead tree.

Caloplaca adriatica (Zahlbr.) Servit, Loc 5 on calcareous rock.

Caloplaca cerina (Ehrh. ex Hedw.) Th.Fr., Loc 1 on Fraxinus ornus, on Juniperus

oxycedrus; Loc 4, Loc 5 on Sorbus torminalis; Loc 8 on Acer sp.

Candelariella aurella (Hoffm.) Zahlbr., Loc 1 on Fraxinus ornus.

Candelariella vitellina (Hoffm.) Müll.Arg., Loc 1 on Fraxinus ornus.

+ * Catapyrenium psoromoides (Borrer) R. Sant., Loc 3 on moss on calcareous rock.

Circinaria calcarea (L.) Mudd, Loc 1, Loc 5 on calcareous rock. 
Circinaria contorta subsp hoffmanniana S.Ekman \& Fröberg ex R.Sant., Loc 4, Loc

5 on calcareous rock.

Cladonia fimbriata (L.) Fr., Loc 1, Loc 5 on dead tree; Loc 2 on moss on dead tree;

Loc 7 on soil.

* Cladonia parasitica (Hoffm.) Hoffm., Loc 1 on dead tree; on Cedrus libani.

* Clauzadea chondrodes (A.Massal.) Clauzade \& Cl.Roux, Loc 2 on calcareous rock.

Clauzadea immersa (Weber) Hafellner \& Bellem., Loc 1, Loc 2 on calcareous rock.

* Clauzadea monticola (Ach.) Hafellner \& Bellem., Loc 5 on calcareous rock.

Collema furfuraceum (Arnold) Du Rietz, Loc 4 on Sorbus torminalis.

Collema nigrescens (Huds.) DC., Loc 1 on Acer sp.; Loc 5 on Sorbus torminalis; Loc

8 on Cedrus libani.

Evernia prunastri (L.) Ach., Loc 1, Loc 5 on Cedrus libani.

* Fuscopannaria mediterranea (C.Tav.) P.M.Jørg., Loc 5 on Acer sp.

Fuscopannaria olivacea (P.M.Jørg.) P.M.Jørg., Loc 4 on dead tree.

Gyalolechia flavorubescens (Huds.) Søchting, Frödén \& Arup, Loc 1 on Fraxinus ornus; Loc 5 on Sorbus torminalis.

Hypocenomyce scalaris (Ach. ex Lilj.) M.Choisy, Loc 3 on dead tree.

Hypogymnia tubulosa (Schaer.) Hav., Loc 1, Loc 2, Loc 3, Loc 4, Loc 7 on Cedrus libani; Loc 1 on dead tree.

* Hypogymnia vittata (Ach.) Parrique, Loc 2 on Cedrus libani.

* Lathagrium auriforme (With.) Otálora, P.M.Jørg. \& Wedin, Loc 4 on moss on

calcareous rock.

Lathagrium cristatum (L.) Otálora, P.M.Jørg. \& Wedin, Loc 5 on calcareous rock.

* Lecania cuprea (A.Massal.) van den Boom \& Coppins, Loc 2 on calcareous rock.

Lecania cyrtella (Ach.) Th.Fr., Loc 1 on Cedrus libani.

* Lecania naegelii (Hepp) Diederich \& P. Boom, Loc 1 on Cedrus libani; on

Juniperus oxycedrus.

Lecanora carpinea (L.) Vain., Loc 1 on Fraxinus ornus; Loc 2 on Cedrus libani; Loc

5 on Sorbus torminalis; Loc 6 on Acer sp..

Lecanora chlarotera Nyl., Loc 1 on Fraxinus ornus; Loc 2 on Cedrus libani; Loc 4, Loc 5 on Sorbus torminalis; Loc 6 on Acer sp.

Lecanora pulicaris (Pers.) Ach., Loc 2 on Cedrus libani.

Lecanora saligna (Schrad.) Zahlbr., Loc 1 on Fraxinus ornus.

Lecanora varia (Hoffm.) Ach., Loc 3 on dead tree.

Lecidella carpathica Körb., Loc 3 on calcareous rock.

Lecidella elaeochroma (Ach.) M.Choisy, Loc 1 on Fraxinus ornus; Loc 1, Loc 2, Loc 6 on Cedrus libani; Loc 3 on Juniperus excelsa; Loc 5, Loc 6 on Acer sp.; Loc 8 on Juniperus excelsa, on Fraxinus ornus, on Acer sp; Loc 4, Loc 5 on Sorbus torminalis.

* Lecidella scabra (Taylor) Hertel \& Leuckert, Loc 5 on dead tree.

Lecidella stigmatea (Ach.) Hertel \& Leuckert, Loc 2, Loc 4, Loc 5 on calcareous rock.

Lepra albescens (Huds.) Choisy \& Werner, Loc 1 on dead tree, Loc 1, Loc 3, Loc 4, Loc 5, Loc 6, Loc 7 on Cedrus libani; Loc 1 on Juniperus oxycedrus; Loc 3 on Juniperus excelsa; Loc 5 on Fraxinus ornus, on Acer sp; Loc 5 on Sorbus torminalis.

* Lepraria umbricola Tønsberg, Loc 3 on dead tree.

Lepraria vouauxii (Hue) R.C.Harris, Loc 5 on moss on calcareous rock.

Leproplaca xantholyta (Nyl.) Hue, Loc 2, Loc 5 on calcareous rock.

Leptogium saturninum (Dicks.) Nyl., Loc 1 on Acer sp. 
Letharia vulpina (L.) Hue, Loc 1 on dead tree; Loc 3,Loc 6, Loc 7 on Cedrus libani, on dead tree.

* Lobaria pulmonaria (L.) Hoffm., Loc 1 on Cedrus libani.

Lobothallia radiosa (Hoffm.) Hafellner, Loc 5 on calcareous rock.

Megaspora verrucosa (Ach.) Hafellner \& V.Wirth, Loc 3 on Juniperus excelsa; Loc 8 on Acer sp., on Cedrus libani.

Melanohalea elegantula (Zahlbr.) O. Blanco, A. Crespo, Divakar, Essl., D. Hawksw. \& Lumbsch, Loc 1, Loc 2, Loc 3 on Cedrus libani, on Juniperus excelsa.

Melanohalea exasperata (De Not.) O.Blanco et al., Loc 4 on Sorbus torminalis, Loc 6 on Acer sp.

Melanohalea exasperatula (Nyl.) O.Blanco et al., Loc 8 on Acer sp.

* Mycobilimbia tetramera (De Not.) Vitik., Ahti, Kuusinen, Lommi \& T.Ulvinen,

Loc 5 on moss on calcareous rock.

Myriolecis pruinosa (Chaub.) Sliwa, Zhao Xin \& Lumbsch Loc 5 on calcareous rock. Nephroma laevigatum Ach., Loc 4 on Cedrus libani; Loc 5 on Acer sp., on dead tree. Nephroma tangeriense (Maheu \& A.Gillet) Zahlbr., Loc 1 on Acer sp.

Ochrolechia balcanica Vers., Loc 1, Loc 2, Loc 3 on Cedrus libani; Loc 4 on dead tree; Loc 4, Loc 5 on Sorbus torminalis; Loc 5, Loc 8 on Acer sp.

Ochrolechia pallescens (L.) A.Massal., Loc 2, Loc 3, Loc 8 on Cedrus libani; Loc 5, Loc 8 on Acer sp.

* Ochrolechia parella (L.) A.Massal., Loc 1 on Acer sp.; Loc 8 on Cedrus libani.

* Ochrolechia tartarea (L.) A.Massal., Loc 5 on Acer sp.

Ochrolechia turneri (Sm.) Hasselrot, Loc 3 on Cedrus libani; Loc 8 on Juniperus excelsa.

* Pannaria conoplea (Ach.) Bory, Loc 8 on Cedrus libani.

+ * Parmelia ernstiae Feuerer \& A. Thell., Loc 3 on Cedrus libani.

Parmelia saxatilis (L.) Ach., Loc 1, Loc 2, Loc 4, Loc 5 on Cedrus libani; Loc 1, Loc

4, Loc 5 on dead tree; Loc 1, Loc 5 on Acer sp.

Parmelia sp. (young individual), Loc 1 on Juniperus oxycedrus.

Parmelia submontana Nadv. ex Hale, Loc 2, Loc 8 on Cedrus libani; Loc 4 on

Sorbus torminalis.

Parmelia sulcata Taylor, Loc 1, Loc 6 on Cedrus libani.

Parmelina pastillifera (Harm.) Hale, Loc 1 on Cedrus libani, on Fraxinus ornus; Loc

5 on Acer sp.

Parmelina tiliacea (Hoffm.) Hale, Loc 1 on Cedrus libani; Loc 5 on dead tree.

Pectenia atlantica (Degel.) P.M. Jørg., L. Lindblom, Wedin \& S. Ekman, Loc 1, Loc 8 on Acer sp; Loc 3, Loc 8 on Cedrus libani, Loc 4 on dead tree.

Peltigera canina (L.) Willd., Loc 4, Loc 5 on moss on calcareous rock, Loc 5 on dead tree, on moss on Acer sp.

Peltigera collina (Ach.) Schrad., Loc 2 on moss on dead tree; Loc 4 on moss on soil;

Loc 5 on dead tree, on Acer sp; Loc 8 on Cedrus libani.

Peltigera membranacea (Ach.) Nyl. Loc 1 on on soil on moss

Peltigera rufescens (Weiss) Humb., Loc 1 on dead tree.

Pertusaria pertusa (Weigel) Tuck., Loc 1 on Acer sp.

Phlyctis agelaea (Ach.) Flot., Loc 1 on Acer sp, on Cedrus libani.

Phlyctis argena (Sprengel) Flot., Loc 1, Loc 8 on Fraxinus ornus, on Juniperus

oxycedrus; Loc 2, Loc 6, Loc 8 on Cedrus libani.

Physcia adscendens (Fr.) H.Olivier, Loc 1 on Fraxinus ornus; Loc 1, Loc 8 on 
Cedrus libani; Loc 8 on Acer sp; Loc 3 on Juniperus excelsa.

Physconia distorta (With.) J.R.Laundon, Loc 1, Loc 3 on Cedrus libani; Loc 1 on Fraxinus ornus; Loc 3 on Juniperus excelsa; Loc 4, Loc 5 on Sorbus torminalis, Loc 5, Loc 8 on Acer sp.; Loc 4 on dead tree.

Physconia venusta (Ach.) Poelt, Loc 3 on Cedrus libani, on Juniperus excelsa; Loc 4 on dead tree.

Placynthium nigrum (Huds.) Gray, Loc 3, Loc 5 on calcareous rock.

Platismatia glauca (L.) W.L.Culb. \& C.F.Culb., Loc 1, Loc 2, Loc 3, Loc 4, Loc 5, Loc 6, Loc 7 on Cedrus libani; Loc 1, Loc 5 on dead tree; Loc 1 on Acer sp.

* Protoblastenia calva (Dicks.) Zahlbr., Loc 2 on calcareous rock.

Pseudevernia furfuracea (L.) Zopf var. ceratea, Loc 1 on Acer sp.; Loc 8 on

Juniperus excelsa; Loc 2, Loc 3 on Cedrus libani.

* Pseudevernia furfuracea (L.) Zopf var. furfuracea, Loc 1 on Juniperus oxycedrus; Loc 1, Loc 2, Loc 3, Loc 4, Loc 5, Loc 6, Loc 7 on Cedrus libani; Loc 6 on Acer sp. Psora vallesiaca (Schaer.) Timdal, Loc 5 on calcareous rock.

Pyrenodesmia chalybaea (Fr.) A.Massal., Loc 4 on calcareous rock.

Pyrenodesmia variabilis (Pers.) A.Massal., Loc 1, Loc 4 on calcareous rock.

* Ramalina calicaris (L.) Fr., Loc 1 on Fraxinus ornus; Loc 5 on Acer sp.

Ramalina farinacea (L.) Ach., Loc 1 on Acer sp., on Cedrus libani, on Juniperus oxycedrus, on Fraxinus ornus; Loc 2 on Cedrus libani.

Ramalina fastigiata (Pers.) Ach., Loc 1 on Fraxinus ornus.

Ramalina fraxinea (L.) Ach., Loc 1 on Acer sp., on Fraxinus ornus; Loc 2, Loc 3 on Cedrus libani.

* Ricasolia amplissima (Scop.) De Not., Loc 1 on Cedrus libani.

Rinodina capensis Hampe in A.Massal., Loc 1 on Fraxinus ornus.

* Rinodina oleae Bagl., Loc 4 on Sorbus torminalis; Loc 8 on Acer sp.

* Rinodina pyrina (Ach.) Arnold, Loc 6 on Acer sp.

* Rinodina sophodes (Ach.) A.Massal., Loc 4 on Sorbus torminalis.

Scytinium gelatinosum (With.) Otálora, P.M.Jørg. \& Wedin, Loc 4, Loc 5 on moss on calcareous rock; Loc 5 on calcareous rock.

Scytinium lichenoides (L.) Otálora, P.M.Jørg. \& Wedin, Loc 5 on moss on calcareous rock.

Scytinium teretiusculum (Wallr.) Otálora, P.M.Jørg. \& Wedin, Loc 8 on Cedrus libani.

Squamarina cartilaginea (With.) P.James, Loc 3, Loc 5 on calcareous rock.

Squamarina gypsacea (Sm.) Poelt, Loc 3 on calcareous rock.

+ * Sticta limbata (Sm.) Ach., Loc 1 on Cedrus libani.

\#* Toninia subfuscae (Arnold) Timdal, Loc 5 on Lecidella scabra.

Variospora aurantia (Pers.) Arup, Frödén \& Søchting, Loc 2 on calcareous rock.

Variospora flavescens (Huds.) Arup, Søchting \& Frödén, Loc 2 on calcareous rock.

Variospora velana (A.Massal.) Arup, Søchting \& Frödén, Loc 2 on calcareous rock. Verrucaria nigrescens Pers., Loc 3, Loc 4, Loc 5 on calcareous rock.

Verruculopsis lecideoides (A.Massal.) Gueidan \& Cl. Roux, Loc 2 on calcareous

rock.

Xanthocarpia lactea (A.Massal.) A.Massal., Loc 5 on calcareous rock.

* Xanthoria isidioidea (Beltram.) Szatala, Loc 4 on Cedrus libani. 


\section{Results of data analysis}

The results obtained from this study and the results obtained from Elmalı Cedar Research Forest (Çobanoglu and Sevgi, 2006) and Termessos National Park (Tufan et al., 2005) were compared. In Elmalı Cedar Research Forest (Çobanoğlu and Sevgi, 2006), only the richness of epiphytic lichenized fungi had been investigated. Therefore, the similarity study for this area was applied only for epiphytic lichens. 54 epiphytic lichenized fungi taxa had been determined from Elmalı Cedar Research Forest and 77 epiphytic lichenized fungi taxa (without lichenicolous fungi) were identified in the Alacadağ Nature Protection Area. The epiphytic lichenized fungi taxa of the Elmalı Cedar Research Forest and the Alacadag Nature Protection Area were found to be $0.4122 \%$ similar (27 common taxa) according to the Sorensen similarity index. 160 lichenized fungi taxa had been determined from Termessos National Park (Tufan et al., 2005). $39.007 \%$ similarity (55 common taxa) was determined between the lichenized fungi richness of Alacadağ Nature Protection Area and the lichenized fungi richness of Termessos National Park.

\section{Discussion}

Antalya, in Southern-west of Turkey, has been visited many times by lichen systematic researchers. A total of 402 lichenized and lichenicolous fungi taxa had been identified including the center city and districts of Antalya (Fellows, 1841; Pišút, 1970; Ayaşligil, 1987; Lumbsch, 1989; John, 1992, 1995, 1996, 2000, 2007; Zeybek et al., 1993; Vězda, 1996; Nimis and John, 1998; Schindler, 1998; Litterski and Otte, 2002; Meyer, 2002; Halda, 2003; Breuss and John, 2004; Çobanoğlu, 2005; Tufan et al., 2005; Schiefelbein, 2006; Mayrhofer and Sheard, 2007; Yavuz and Çobanoğlu, 2007; Pišút and Guttová, 2008; Kocakaya et al., 2009; Tufan-Cetin and Sümbül, 2011; Halici et al., 2012; Kocakaya et al., 2014; Özdemir Turk et al., 2015; Tufan-Çetin, 2015, 2019; Vondrák et al., 2016; John and Turk, 2017). In this study, 124 taxa belong to 9 orders, 27 families and 66 genera were determined. 33 of these were recorded for the first time in Antalya and the number of lichenized and lichenicolous fungi taxa of Antalya reach to 435 .

Three of the taxa identified in the research area are lichenicolous fungi that live parasitically on lichens. A lichenicolous fungus species, Abrothallus welwitschia, is newly recorded for Turkey. Abrotallus is a genus that does not have a clear similarity to other genera of Ascomycetes and has many hypotheses about its phylogenetic relations (Pérez-Ortega et al., 2014). It is mostly composed of parasitic fungi living on lichens. World distirubition of Abrothallus welwitschii is Europe (France, England, Ireland, Spain, Portugal), New Zealand, Africa (Kenya), North America (America), South America (Chile). Abrothallus welwitschii mostly choses species belonging to the genus Sticta as host (Suija et al., 2015). In this study, this species was determined over Sticta limbata. Stict limbata was determined first time in Turkey from Alacadağ Nature Protection Area. Also Stict limbata is found in the Northern Hemisphere, South Africa, South America, Australia, New Zealand and East Asia (Japan, China, Korea) (Jayalal et al., 2014). Also the taxon in red list was categorized as "vulnerable" in Italy (Nascimbene et al., 2013). This species was reported living on mossy tree bark in the old forests by Smith et al. (2009). Similarly, in our research area, the species was identified from old Cedrus libani trees. 
Calicium pinicola which had been defined as new combination with Cyphelium pinicola Tibell, Svensk Bot. Tidskr by Prieto et al. (2016), was reported as a new record for Turkey from this research area. This species which is located in Austria, Macedonia, USA (Obermayer, 1998) and the Swiss Alps (Nimis et al., 2018), is threatened with extinction in Switzerland (Bürgi-Meyer and Dietrich, 2011), categorized as "vulnerable" in Italy (Nascimbene et al., 2013).

Of the new records for Turkey Catapyrenium psoromoides is a species found in the Southwest of Asia Temperate, East Africa, Europe, New Zealand and North America. It is near threatened with extinction in Italy according to Nascimbene et al. (2013). The taxon lives on trees or on mosses (Breuss, 2002; Prieto et al., 2010). In our study, it was determined also over the moss.

Parmelia ernstia which has a wide distribution in Europe (Austria, Belgium, Bosnia and Herzegovina, Britain, Bulgaria, Czechia, Denmark, Estonia, France, Germany, Greece, Ireland, Lithuania, Luxembourg, Netherlands, Slovenia, Spain, Poland, Sweden), have been recorded from Turkey for the first time by this research. This species is also distributed in Algeria and Canary Islands in Africa (Kukwa et al., 2012). According to Kukwa et al. (2012) this species is rarely seen in coniferous deciduous trees. In Italy, Parmelia ernstia was identified from Quercus and Pinus species (Nimis and Martellos, 2017). Also in this study, the species was recorded on Cedrus libani.

In the Italian red list of epiphytic lichens Calicium pinicola, Hypogymnia vittata, Sticta limbata are categorized as "vulnerable" and Catapyrenium psoromoides; Pannaria conoplea; Ricasolia amplissima are classificated as "near threatened" (Nascimbene et al., 2013). The Alacadağ Nature Protection Area is home to these sensitive species.

Most of the new records for Antalya in this study, have limited distribution in Turkey. In Figure 4, Turkey distribution maps of some taxa are given. The maps were created using the information of John and Türk (2017). There are also maps showing the biogeographical regions and phytogeographical regions of Turkey in Figure $4 \mathrm{~g}$ and $4 \mathrm{~h}$. Arthonia didyma (Figure 4a), Arthonia medulla, Lecania cuprea, Lepraria umbiricola, Mycobilimbia tetramera (Figure 4c), Ramalina calicaris, Ricasolia amplissima (Figure 4e), that had been defined as specific to the Euro-Siberian Phytogeographical Region (P.R.) (Black Sea Biogeographical Region (B.R.)) of Turkey (John and Türk, 2017), have been found newly in Mediterranean Region of Turkey with this study. Protoblastenia calva that was defined only from Irano-Turanian P.R. (Anatolian B.R.) of Turkey have been found in our research area (John and Türk, 2017). Similiarly, Bryoria nadvornikiana, Calicium trabinellum, Hypogymnia vittata (Figure 4b), Pannaria conoplea (Figure 4d), Ochrolechia tartarea, Xanthoria isidioidea were known in both Euro-Siberian P.R. (Black Sea B.R.) and Iran-Turanian P.R. (Anatolia B.R.) of Turkey (John and Türk, 2017). With our study these taxa have been recorded in Turkey's Mediterranean B.R. (Mediterranean P.R.). In addition, Cladonia parasitica which was defined as a lichen of the Euro-Siberian P.R. (Black Sea B.R.) in Turkey, had been found before in the south of Anatolia (in Hatay) same as with our study (John and Türk, 2017). The reason for this species to be found in Hatay may be due to the fact that this region is an enclave of Euro-Siberian P.R. (Black Sea B.R.) (Atalay, 1986). The presence of this species also in the research area may show that the area has a special ecological structure. On the other hand, Rinodina oleae (Figure 4f), Lathagrium auriforme, Lobaria pulmonaria (Figure 5), Ochrolechia parella, Rinodina pyrina which 


$$
-1701 \text { - }
$$

are the new record taxa for Antalya, have a wide geographical distribution in Turkey and have been found in this research area.

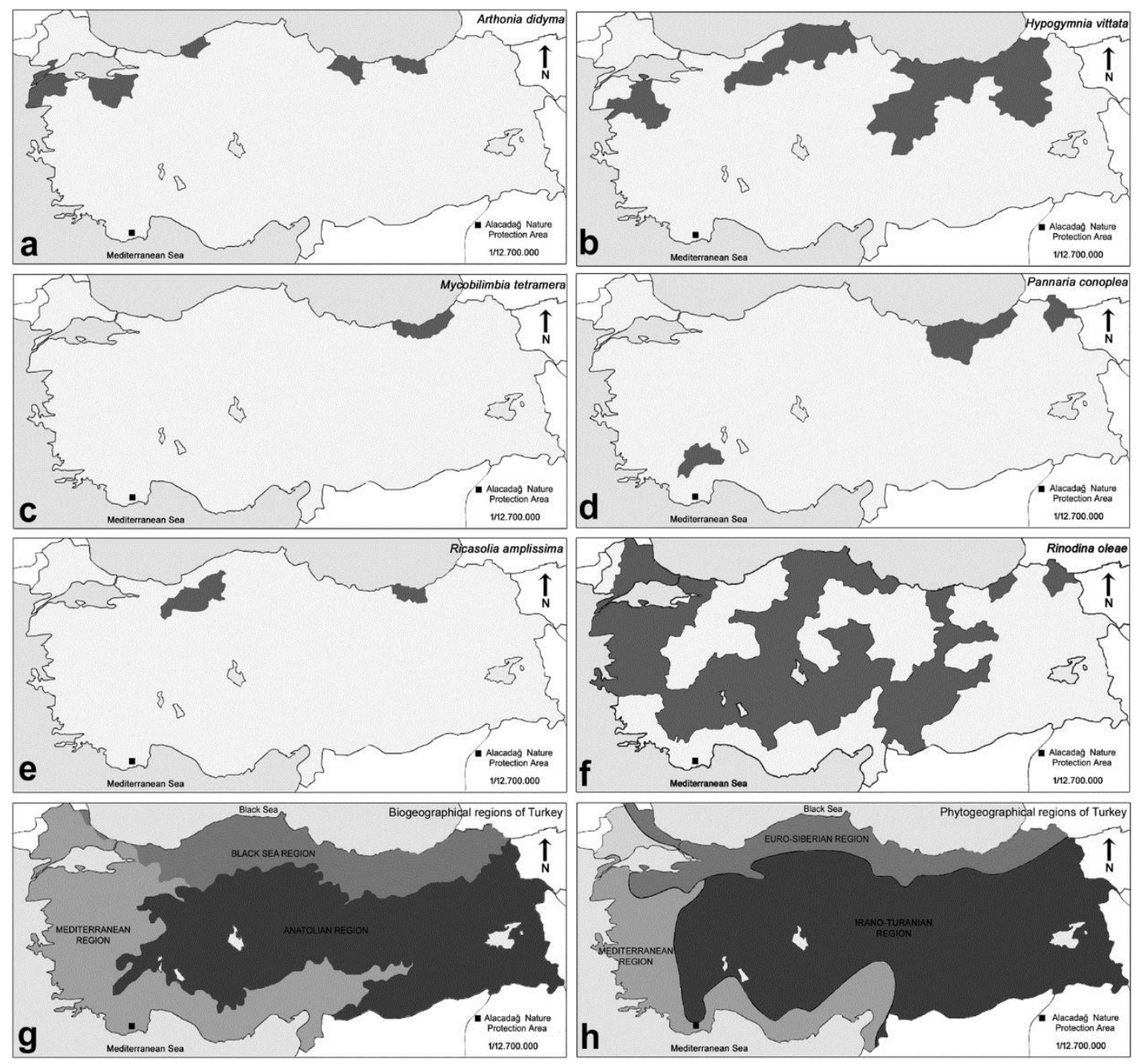

Figure 4. a-f. Turkey distribution map of some lichen taxa from Alacadă̆ Nature Protection Area (a. Arthonia didyma, b. Hypogymnia vittata, c. Mycobilimbia tetramera, d. Pannaria conoplea, e. Ricasolia amplissima, f. Rinodina oleae) g. Biogeographical regions of Turkey $\boldsymbol{h}$. Phytogeographical regions of Turkey

When our richness data were compared with data of the nearby areas, with data of Termessos National Park, one of the compared area, 39.007\% similarity rate were found. In addition, the epiphytic lichenized fungi richness data of the Alacadağ Nature Protection Area were found $0.4122 \%$ similarity with data of Elmalı Cedar Research Forest according to the Sorensen similarity index. However, according to Tufan-Çetin (2019), the richness of Termessos National Park is 55.52\% (according to Sorensen similarity index) similar with the richness of Altınbeşik Cave National Park which is one of the protected areas of Antalya. In addition, Tufan-Çetin and Sumbul (2011) reported that Köprülü Canyon, another national park of Antalya, showed $58.29 \%$ similarity with Termessos National Park (according to Sorensen similarity index). According to these reference comparisons, it is concluded that the species richness 
composition of Alacadağ Nature Protection Area showed low similarity to other areas. Futhermore, it was determined that many of dissimilar taxa (according to compared area) are only species that can live in good environmental conditions and in old forests (Figure 6) (Nimis and Martellos, 2017). Comparison area data dating back 13-14 years before may be the result of the better environmental quality than today. But the fact that these dissimilar taxa in the area can live in good environmental quality may indicate that the environmental change has not occurred in the area.

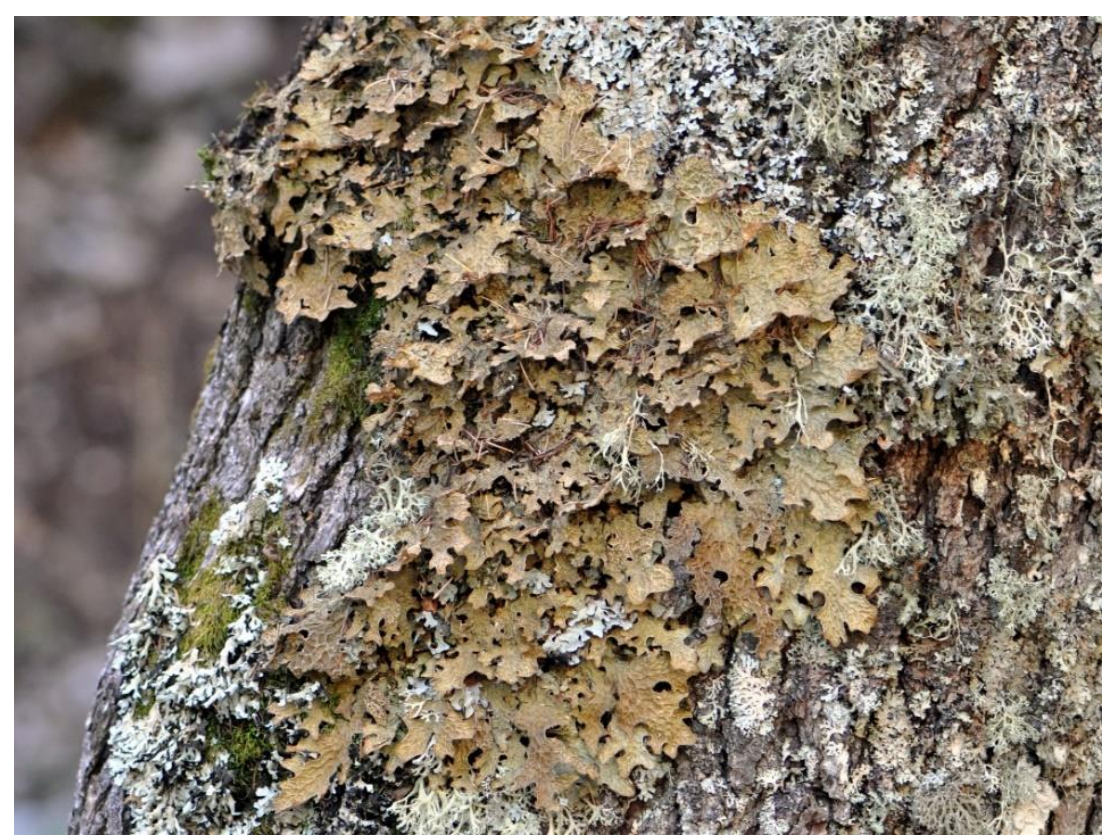

Figure 5. Some lichenized fungi taxa on Cedrus libani stem in Alacada ğ Nature Protection Area (Nature Reserve) Finike-Antalya

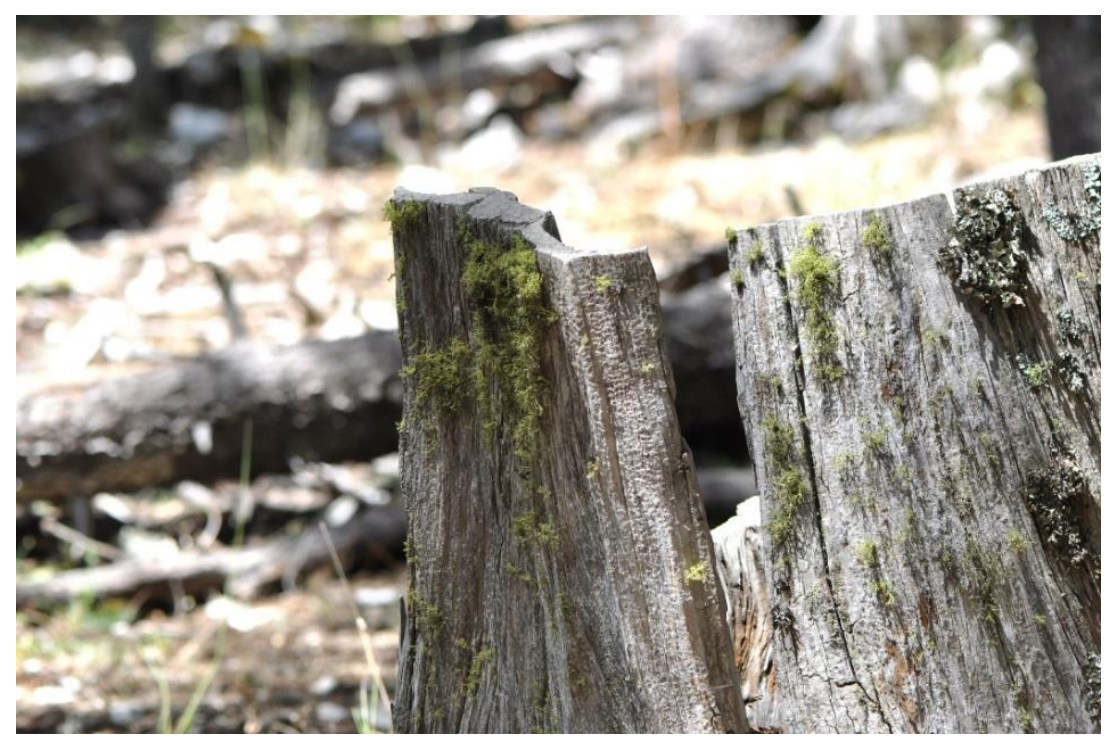

Figure 6. Some old forest lichenized fungi taxa on dead tree in Alacadağ Nature Protection Area (Nature Reserve) Finike-Antalya 


\section{Conclusion}

This study is the first comprehensive study to determine the lichenized and lichenicolous fungi taxa in the Alacadağ Nature Protection Area (Nature Reserve). Many taxa were newly recorded from Turkey, Turkey's Mediterranean region and Antalya Province with this study. Taxa that had been known as specific to different geographical regions of Turkey before, were firstly determined from the area. Furthermore, species richness composition of Alacadağ Nature Protection Area was found low similarity to other areas All these noteworthy species findings indicate a different species composition structure in the Alacadağ Nature Protection Area compared to the Mediterranean lichen composition. In fact, Alacadağ has been declared as nature protection area (Nature Reserve) due to its rich plant diversity. In this study, it was also determined that the area has a different ecological structure in terms of lichens like plant diversity.

Nowadays, on three sides of Alacadağ Nature Protection Area are surrounded by marble quarries (Figure 1). It is obligatory to protect the area, which is emphasized as having a special structure also in this study, from the pressure of marble quarries. It has been observed that the density of sensitive species (Catapyrenium psoromoides, Calicium pinicola, Hypogymnia vittata; Sticta limbata, Pannaria conoplea; Ricasolia amplissima) in the area decreases when it was approached the marble quarries. For this reason, the density of the species in the area should be examined with a further study.

\section{REFERENCES}

[1] Arup, U., Søchting, U., Frödén, P. (2013): A new taxonomy of the family Teloschistaceae. - Nordic Journal of Botany 31(1): 016-083.

[2] Atalay, İ. (1986): Vegetation formations of Turkey. - Travaux de l'Institut Géographique de Reims 65-66: 17-30.

[3] Ayaşligil, Y. (1987): Der Köprülü Kanyon Nationalpark. - Landschaftsökologie Weihenstephan 5: I-XIV, 1-307.

[4] Breuss, O. (2002): Catapyrenium. - In: Nash, T. H., Ryan, B. D., Gries, C., Bungartz, F. (eds.) Lichen Flora of the Greater Sonoran Desert Region. Volume I: 125-128.

[5] Breuss, O., John, V. (2004): New and interesting records of lichens from Turkey. Österreichische Zeitschrift für Pilzkunde 13: 281-294.

[6] Bürgi-Meyer, K., Dietrich, M. (2011): Cyphelium pinicola Tibell in den Nordalpen der Zentralschweiz. Einblicke in den Flechtenreichtum der subalpinen Altwälder am Fusse des Gugels in der UNESCO Biosphäre Entlebuch, Kanton Luzern. - Meylania 7: 11-17.

[7] Clauzade, G., Roux, C. (1985): Likenoj De Okcidenta Eûropo Ilustrita Determinlibro. Bulletin de la Société Botanique du Centre-Ouest Nouvelle série- Numéro Spécial, Royan, France, 893 p.

[8] Çobanoğlu, G. (2005): Lichen collection in the herbarium of the University of Istanbul (ISTF). - Turkish Journal of Botany 29: 69-74.

[9] Çobanoğlu, G., Sevgi, O. (2006): Elmalı Sedir Araştırma Ormanı (Antalya) Epifitik Liken Floras1. - İstanbul Üniversitesi Orman Fakültesi Dergisi Seri A 56(1): 81-88.

[10] Dudley, N. (2008): IUCN Guidelines for Applying Protected Area Management Categories. - Gland, Switzerland.

[11] Eroğlu, S. (2014): Milli Parklar Kanununda Belirlenen Korunan Alan Metodolojisi. Denetişim 13: 85-90.

[12] Fellows, C. (1841): An account of discoveries in Lycia: Being a journal kept during a second excursion in Asia Minor. - London, 290 p. 
[13] Feuerer, T., Hawksworth, D. L. (2007): Biodiversity of lichens, including a world-wide analysis of checklist data based on Takhtajan's floristic regions. - Biodiversity and Conservation 16(1): 85-98.

[14] Gauslaa, Y., Palmqvist, K., Solhaug, K. A., Holien, H., Hilmo, O., Nybakken, L., Ohlson, M. (2007): Growth of epiphytic old forest lichens across climatic and successional gradients. - Canadian Journal of Forest Research 37(10): 1832-1845.

[15] Halda, J. (2003): A taxonomic study of the calcicolous endolitic species of the genus Verrucaria (Ascomycotina, Verrucariales) with the lid-like and radiately opening involucrellum. - Acta Musei Richnoviensis Sect. Nat. 10(1): 1-148.

[16] Halici, M. G., Kocakaya, M., Kılıç, E. (2012): New Candelariella records for Turkey. Mycotaxon 121: 313-318.

[17] Hawksworth, D. L. (1991): The fungal dimension of biodiversity: magnitude, significance, and conservation. - Mycological research 95(6): 641-655.

[18] Hilmo, O., Såstad, S. M. (2001): Colonization of old-forest lichens in a young and an old boreal Picea abies forest: an experimental approach. - Biological Conservation 102(3): 251-259.

[19] Ihlen, P. G., Wedin, M. (2008): An annotated key to the lichenicolous Ascomycota (including mitosporic morphs) of Sweden. - Nova Hedwigia 86:(3-4): 275-365.

[20] Index Fungorum (2018): http://www.indexfungorum.org. - Son erişim tarihi: 14.07.2018.

[21] Jayalal, U., Sohsokim, J. A., Koh, Y. J., Crişan, F., Hur, J. S. (2014): The Lichen Genus Sticta in South Korea. - Mycobiology 42(1): 6-11.

[22] John, V. (1992): Das die Türkei betreffende lichenologische Schrifttum / Türkiye likenleri ile ilgili literatür. - Pfalzmuseum für Naturkunde, Bad Dürkheim, 1-14.

[23] John, V. (1995): Ergänzungen zum die Türkei betreffenden lichenologischen Schrifttum / Türkiye likenleri ile ilgili literatüre ilaveler. - Pfalzmuseum für Naturkunde, Bad Dürkheim, 1-8.

[24] John, V. (1996): Preliminary catalogue of lichenized and lichenicolous fungi of Mediterranean Turkey. - Bocconea 6: 173-216.

[25] John, V. (2000): Lichenes Anatolici Exsiccati. Fasc. 4-5 (no. 76-125). - Arnoldia 19: 127.

[26] John, V. (2007): Lichenological studies in Turkey and their relevance to environmental interpretation. - Bocconea 21: 85-93.

[27] John, V., Turk, A. (2017): Türkiye Likenleri Listesi. - Nezahat Gökyiğit Botanik Bahçesi Yayın1, İstanbul, $666 \mathrm{~s}$.

[28] Knapp, S., Kühn, I., Mosbrugger, V., Klotz, S. (2008): Do protected areas in urban and rural landscapes differ in species diversity? - Biodiversity and Conservation 17(7): 15951612 .

[29] Kocakaya, M., Halici, M. G., Aksoy, A. (2009): Lichens and lichenicolous fungi of Kızıldağ (Derebucak, Konya). - Turkish Journal of Botany 33: 105-112.

[30] Kocakaya, M., Halici, M. G., Aksoy, A. (2014): Lichenized and lichenicolous fungi of Gevne valley (Konya, Antalya). - Turkish Journal of Botany 38(2): 358-369.

[31] Kukwa, M., Łubek, A., Szymczyk, R., Zalewska, A. (2012): Seven lichen species new to Poland. - Mycotaxon 120(1): 105-118.

[32] Litterski, B., Otte, V. (2002): Biogeographical research on european species of selected lichen genera. - Bibliotheca Lichenologica 82: 83-90.

[33] Lumbsch, H. T. (1989): Die holarktischen Vertreter der Flechtengattung Diploschistes (Thelotremataceae). - Journal of the Hattori Botanical Laboratory 66: 133-196.

[34] Mayrhofer, H., Sheard, J. W. (2007): Rinodina archaea (Phsyciaceae, lichenized Ascomycetes) and related species. - Bibliotheca Lichenologica 96: 229-246.

[35] Meyer, B. (2002): Die Flechtengattung Clauzadea. - Sendtnera 8: 85-154.

[36] Mitchell, B. A., Stolton, S., Bezaury-Creel, J., Bingham, H. C., Cumming, T. L., Dudley, N., Fitzsimons, J. A., Malleret-King, D., Redford, K. H., Solano, P. (2018): Guidelines 
for privately protected areas. - Best Practice Protected Area Guidelines Series No. 29. Gland, Switzerland: IUCN. xii + 100 pp.

[37] Moberg, R. (1977): The lichen genus Physcia and allied genera in Fennoscandia, Stockholm. - Symbolae Botanicae Upsaliensis 22(1): 1-108.

[38] MPK (1983): Milli Parklar Kanunu. - Resmi Gazete (National Park Law, official newspaper) 5: 508-530.

[39] Nascimbene, J., Nimis, P. L., Ravera, S. (2013): Evaluating the conservation status of epiphytic lichens of Italy: a red list. - Plant Biosystems-An International Journal Dealing with all Aspects of Plant Biology 147(4): 898-904.

[40] Nimis, P. L., John, V. (1998): A contribution to the lichen flora of Mediterranean Turkey. - Cryptogamie: Bryologie, Lichénologie 19: 35-58.

[41] Nimis, P. L., Martellos, S. (2017): ITALIC - The Information System on Italian Lichens. Version 5.0. - University of Trieste, Dept. of Biology, http://dryades.units.it/italic, [Son erişim tarihi: 20.11.2019].

[42] Nimis, P. L., Hafellner, J., Roux, C., Clerc, P., Mayrhofer, H., Martellos, S., Bilovitz, P. O. (2018): The lichens of the Alps-an annotated checklist. - MycoKeys 31: 1.

[43] Obermayer, W. (1998): Dupla Graecensia Lichenum 1998. - Fritschiana 6: 7-14.

[44] Otálora, M. A., Jørgensen, P. M., Wedin, M. (2014): A revised generic classification of the jelly lichens, Collemataceae. - Fungal diversity 64(1): 275-293.

[45] Özdemir Türk, A., Halici, M. G., Candan, M., Yavuz, Y. (2015): The lichenized fungus genus Peltigera in Turkey. - Biological Diversity and Conservation 8(2): 146-156.

[46] Pérez-Ortega, S., Suija, A., Crespo, A., De los Ríos, A. (2014): Lichenicolous fungi of the genus Abrothallus (Dothideomycetes: Abrothallales ordo nov.) are sister to the predominantly aquatic Janhulales. - Fungal Diversity 64(1): 295-304.

[47] Pišút, I. (1970): Interessante Flechtenfunde aus der Türkei. - Preslia, Praha 42: 370-383.

[48] Pišút, I., Guttová, A. (2008): Contribution to the lichen flora of Anatolia, Turkey. Sauteria 15: 403-415.

[49] Prieto, M., Gregorio, A., Isabel, M. (2010): The genus Catapyrenium s. lat. (Verrucariaceae) in the Iberian Peninsula and the Balearic Islands. - The Lichenologist 42(6): 637-684.

[50] Prieto, M., Mats, W. (2016): Phylogeny, taxonomy and diversification events in the Caliciaceae. - Fungal Diversity 82: 221-238.

[51] Schiefelbein, U. (2006): Ökologische und naturschutzfachliche Aspekte der Flechtenflora des Landkreises Uecker-Randow (Mecklenburg-Vorpommern). - Archiv naturwissenschaftlicher Dissertationen 16: 1-216.

[52] Schindler, H. (1998): Beitrag zur Flechtenflora von Westanatolien, Türkei. - Herzogia 13: 234-237.

[53] Smith, C. W., Aptroot, A., Coppins, B. J., Fletcher, A., Gilbert, O. L., James, P. W., Wolseley, P. A. (2009): The Lichens of Great Britain and Ireland. - British Lichen Society, London, 1046 p.

[54] Sørensen, T. (1948): A method of establishing groups of equal amplitude in plant sociology based on similarity of species and its application to analyses of the vegetation on Danish commons. - Kongelige Danske Videnskabernes Selskab Biologiske Skrifter 5: $1-34$.

[55] Suija, A., Pérez-Ortega, S. (2015): A molecular reappraisal of Abrothallus species growing on lichens of the order Peltigerales. - Phytotaxa 195(3): 201-226.

[56] Tripp, E. (2017): Field Guide to the Lichens of White Rocks: (Boulder, Colorado). University Press of Colorado.

[57] Tucker, S., Thiers, H. (1998): Key to crustose lichen genera of California. - Bulletin of the California Lichen Society 5(1): 1-18.

[58] Tufan, Ö., Sümbül, H., Özdemir Türk, A. (2005): The lichen flora of the Termessos National Park in southwestern Turkey. - Mycotaxon 94: 43-46. www.mycotaxon.com/resources/weblists.html 


$$
\text { - } 1706 \text { - }
$$

[59] Tufan-Cetin, Ö., Sümbül, H. (2011): Lichens of the Köprülü Canyon National Park in Turkey. - Mycotaxon 115: 534-536. (in Regional annoted mycobiotas new to www.mycotaxon.com).

[60] Tufan-Çetin, Ö. (2015): Phaselis Antik Kenti (Antalya) Likenleri I. - Phaselis 1: 133-141.

[61] Tufan-Çetin, Ö. (2019): Determination of lichen diversity variations in habitat type of Mediterranean maquis and arborescent matorral. - Applied Ecology and Environmental Research 17: 10173-10193.

[62] Vězda, A. (1996): Lichenes Rariores Exsiccati. Fasc. 22 (No 211-220). - Brno: 1-4.

[63] Vondrák, J., Halici, M. G., Güllü, M., Demirel, R. (2016): Taxonomy of the genus Athallia and its diversity in Turkey. - Turkish Journal of Botany 40(3): 319-328.

[64] Wirth, V. (1995): Die Flechten Baden-Württembergs. Teil: 1-2. - Eugen GmbH \& Co. Stuttgart, $1006 \mathrm{p}$.

[65] Yavuz, M., Çobanoğlu, G. (2007): Kozalak likenleri, TLT Antalya araştırma gezisinden liken kayıtları. - TLT bülteni 4: 5-6.

[66] Yuan, X., Xiao, S., Taylor, T. N. (2005): Lichen-like symbiosis 600 million years ago. Science 308(5724): 1017-1020.

[67] Zeybek, U., John, V., Lumbsch, H. T. (1993): Türkiye likenlerinden Hypogymnia (Nyl.) Nyl. cinsi üzerinde taksonomik araştırma. - Doğa, Tr. J. of Botany 17: 109-116. 